\title{
PERMASALAHAN DALAM PENERAPAN MEKANISME PASAR PERSPEKTIF ISLAM
}

\author{
Tri Wahyuni \\ Institut Agama Islam Agus Salim Metro, Lampung \\ Email: alqahdi@iai-agussalimmetro.ac.id
}

\begin{abstract}
The market is a place for economic activity where economic activities take place naturally so that the rules of the game occur naturally. So according to Islamic economics the market mechanism can occur naturally from the supply and demand side as it should. Furthermore, in terms of the market mechanism of the Islamic economic perspective, in principle, it rejects the existence of a price intervention if price changes occur because the market mechanism is reasonable. However, the market here requires morality, among others: fair competition, honesty, transparency and justice. If these values have been enforced, there is no reason to reject market prices. And if there is a deviation, the state's obligation to regulate it is for the benefit of the people.
\end{abstract}

Keywords : Market Mecanisme Implementations

\section{DASAR PEMIKIRAN}

Pasar adalah sebuah mekanisme pertukaran barang dan jasa yang alamiah dan telah berlangsung sejak peradaban awal manusia. Islam menempatkan pasar pada kedudukan yang penting dalam perekonomian. Praktik ekonomi pada masa Rasulullah dan Khullafaurrasyidin menunjukan adanya peranan pasar yang besar. Rasulullah sangat menghargai harga yang dibentuk oleh pasar sebagai harga yang adil. Beliau menolak adanya suatu price intervention seandainya perubahan harga terjadi karena mekanisme pasar yang wajar. Namun, pasar di sini mengharuskan adanya moralitas, anatara lain: persaingan yang sehat (fair play), kejujuran (honesty), keterbukaan (transparancy), dan keadilan (justice). Jika nilai-nilai ini telah ditegakkan, maka tidak ada alasan untuk menolak harga pasarDisarikan dari ( MM. Metwally, 1995:1-6 ).

Catatan sejarah memaparkan bagaimana Rasulullah menghargai mekanisme pasar sebagai sebuah sunnatullah yang harus dihormati. Pandangan tentang pasar dan harga dari beberapa pemikir besar muslim seperti Abu Yusuf, Al-Ghazali, IbnKhaldun, Ibn 
Taimiyah juga diungkap. Pemikiran-pemikiran mereka tentang pasar ternyata sangat canggih dan tergolong futuristik jika dipandang pada masanya. Pemikiran-pemikran mereka tentu saja merupakan kekayaan khasanah intelektual yang sangat berguna pada masa kini dan masa depan. Selanjutnya dipaparkan bagaimana mekanisme kerja pasar serta faktor-faktor yang memengaruhinya. Beberapa bentuk transaksi bisnis yang dianggap tidak Islami yang umum dipraktikan masyarakat Arab pada waktu itu. Berikut akan dipaparkan mekanisme pasar sebagaimana dikonsepkan para pemikir Islam Klasik.

Pasar memegang peranan penting dalam perekonomian masyarakat Muslim pada masa Rasulullah SAW dan Khulafaurrasyidin. Bahkan, Muhammad SAW sendiri pada awalnya adalah seorang pebisnis, demikian pula Khulafaurrasyidin dan kebanyakan sahabat. Pada saat awal perkembangan Islam di Makkah Rasulullah SAW dan masyarakat Muslim mendapat gangguan dan terror yang berat darimasyarakat kafir Makkah sehingga perjuangan dan dakwah merupakan prioritas. Ketika masyarakat Muslim telah berhijrah ke Madinah, peran Rasulullah SAW bergeser menjadi pengawas pasar atau Al- muhtasib.

Berbicara mengenai mekanisme pasar dalam dasar hukum Islam yang pertama yaitu al Qur'an, tentu saja al Qur'an sebagai dasar filosofi hidup manusia tidak memberikan aturan secara jelas tentang apa itu mekanisme pasar. Namun demikian sebagai manusia yang dilengkapi akal maka kita akan dapatkan aturan main tentang pasar yaitu seperti apa yang tersebut dalam al Qur'an surat An-Nisa (4) ayat 29.

Pada saat itu mekanisme pasar sangat dihargai. Beliau menolak untuk membuat kebijakan penetapan harga manakala tingkat harga di Madinah pada saat itu tiba-tiba naik. Sepanjang kenaikan terjadi karena kekuatan permintaan dan penawaran yang murni, yang tidak dibarengi dengan dorongan-dorongan monopilistik danmonopsonistik, maka tidak ada alasan untuk tidak menghormati harga pasar. Dalam suatu Hadits dijelaskan bahwa pasar merupakan hukum alam (Sunnatullah) yang harus dijunjung tinggi. Tak seorang pun secara individual dapat mempengaruhi pasar, sebab pasar adalah kekuatan kolektif yang telah menjadi ketentuan Allah SWT. Pelanggaran terhadap harga pasar, misalnya penetapan harga dengan cara dan karena alasan yang tidak tepat, merupakan suatu ketidak adilan (injustice) yangakan dituntut pertanggung jawabannya dihadapan Allah dan begitu pun sebaliknya.Penghargaan Islam terhadap 
mekanisme pasar berdasar pada ketentuanAllah SWT bahwa perniagaan harus dilakukan secara baik dengan rasa suka samasuka serta nilai moralitas mutlak harus ditegakkan. Secara khusus nilai moralitasyang mendapat perhatian penting dalam pasar adalah persaingan yang sehat, kejujuran, keterbukaan, dan keadilan.

Berbicara mengenai masalah mekanisme pasar maka pertanyaan yang muncul tentu masalah keseimbangan dalam pasar. Keseimbangan atau ekuilibrium menggambarkan suatu situasi dimana semua kekuatan yang ada dalam pasar, permintaan dan penawaran, berada dalam keadaan seimbang sehingga setiap variabelyang terbentuk di pasar, harga dan kuantitas sudah tidak lagi berubah. Dalam keadaan ini harga dan kuantitas yang diminta akan sama dengan yang ditawarkan sehingga terjadilah transaksi. Selanjutnya, proses terjadinya keseimbangan dalam pasar dapat berawal dari sisi mana saja, baik dari permintaan ataupun penawaran. Adapun perubahan keseimbangan dapat melalui:-perubahan berasal dari sisi permintaan, perubahan berasal dari sisi penawaran, perubahan berasal dari sisi penawaran dan permintaan( Adiwarman A. Karim, 2007: 162-163 ).

\section{PEMBAHASAN}

\section{Pasar dalam Perspektif Pemikir Muslim}

Mekanisme pasar dibangun atas dasar kebebasan, yakni kebebasan individu untuk melakukan transaksi barang dan jasa. Sistem ekonomi Islam menempatkan kebebasan pada posisi yang tinggi dalam kegiatan ekonomi. Bahkan, Rasulullah SAW. tidak menganjurkan campur tangan apapun dalam proses penentuan harga dan intervensi harga oleh negara atau individual (Aravik, 2016: 146).

Mekanisme Pasar Menurut Abu Yusuf (731-798 M), dapat dijumpai dalam bukunya Al-Kharaj yang membahas prinsip-prinsip perpajakan dan anggaran negara yang menjadi Pedoman Kekhalifahan Harun Al-Rasyid di Baghdad. Ia menyimpulkan bekerjanya hukum permintaan dan penawaran pasar dalam menentukan tingkat harga, meskipun kata permintaan dan penawaran ini tidak ia katakana secara eksplisit. Selain itu dalam bukunya secara implisit juga dijelaskan bahwa, harga bukan hanya ditentukan oleh penawaran saja, tetapi juga permintaan terhadap barang tersebut. Bahkan, Abu Yusuf mengidikasikan adanya variable-variabel lain yang juga turut mempengaruhi 
harga, misalnya jumlah uang beredar di Negara itu, penimbunan atau penahanan suatu barang, atau lainnya (Abu Yusuf ibn Ya'qub ibn Ibrahim 1992 : 15-16 )

Al-Ihya Ulumuddin karya Al-Ghazali banyak membahas topik-topik ekonomi, termasuk pasar. Dalam karyanya tersebut ia membicarakan barter dan permasalahannya, pentingnya aktivitas perdagangan dan evolusi terjadinya pasar,termasuk bekerjanya kekuatan permintaaan dan penawaran dalam mempengaruhi harga. Al-Ghazali menyadari kesulitan yang timbul akibat sistem barter yang dalam istilah ekonomi modern disebut double coincidence, dan karena itu diperlukan suatu pasar. Selain itu Al-Ghazali juga telah memahami suatu konsep, yang sekarang kita sebut elastisitas permintaan. Hal ini tampak jelas dari perkataaannya bahwa mengurangi margin keuntungan dengan menjual harga yang lebih murah akan meningkatkan volume penjualan, dan ini pada gilirannya akan meningkatkan keuntungan (Abul Hasan M, 2002: 95-96)

Pemikiran Ibn Taimiyah mengenai mekanisme pasar banyak dicurahkan melalui bukunya, yaitu Al-Hisbah fi'l Al-Islam dan Majmu' Fatawa. Pandangan IbnTaimiyah mengenai hal ini sebenarnya terfokus pada masalah pergerakan harga yang terjadi pada waktu itu, tetapi ia letakan dalam kerangka mekanisme pasar. Secara umum, beliau telah menunjukan the beauty of market (keindahan mekanisme pasar sebagai mekanisme ekonomi).

Ibn Khaldun sangat menghargai harga yang terjadi dalam pasar bebas, namun ia tidak mengajukan saran-saran kebijakan pemerintah untuk mengelola harga. Ia lebih banyak memfokuskan kepada faktor-faktor yang mempengaruhi harga. Hal ini tentu saja berdeda dengan Ibn Taimiyah yang dengan tegas menentang intervensi pemerintah sepanjang pasar berjalan dengan bebas dan normal (Charles Issawi, 1992: 232- 233).

\section{Mekanisme Pasar Islam Antara Idealita dan Realita}

Dalam ekonomi konvensional, Adam Smith dalam the Wealth of Nation:"Dengan cara mengarahkan produksi, hal ini dapat menggerakkan produksi yang mampu menghasilkan nilai yang paling besar, padahal diahanya meniatkannya untuk keuntungan dirinya sendiri, dan yang demikian, digerakkan oleh tangan yang tak 
Ekonomica Sharia Volume 5 Nomor 1 Edisi Agustus 2019|95

kentara yang mengarahkannya kepada batas yang tidak ia kehendaki( Adam Smith, 1937: 22 ).

Secara singkat Smith mengungkapkan bahwa walaupun setiap orang mengerjakan sesuatu didasarkan kepada kepentingan pribadi, tetapi hasilnya akan lebih efektif dan selaras dengan tujuan masyarakat. Dampak aktivitas setiap individu dalam mengejar kepentingannya masing masing terhadap kemajuan masyarakat, justru lebih baik dibanding dengan tiap orang berusaha untuk memajukan masyarakat. Niat baik pemerintah untuk mensejahterakan masyarakat seringkali berbanding terbalik dengan realita yang terjadi. Filosofi Adam Smith tersebut menjadi akar perkembangan ilmu ekonomi konvensional termasuk bidang kajian mekanisme pasar.

Filosofi Smith ini selanjutnya mendapat kritik tajam dari Marx karena ide-ide Smith hanya akan menguntungkan pemilik modal dan memunculkan sistemkelas. Marx merupakan penentang keras dari mekanisme pasar bebas yang diungkapkan oleh Adam Smith. Ada tiga hal yang menjadi alasannya: 1) Dalam ekonomi. Laissez faire mendorong adanya surplus value dan penguasaan kekayaan oleh segelintir orang. Buruh diperas tenaganya dengan upah minimum, 2) Dalam psikologi. Menimbulkan adanya pertentangan antara kelas tuan tanahdan buruh, 3) Dalam sosial. Masyarakat terpecah menjadi kelas tuan tanah dan buruh.

Namun demikian, hampir semua jatuh bangunnya paradigma ekonomi konvensional ini senantiasa tidak dapat menawarkan sebuah tatanan yang benar-benar berkeadilan dan menjunjung nilai-nilai etika berekonomi yang luhur sehingga semuanya bersifat parsial mengingat orientasinya yang keduniaan saja. Ketika ekonomi kapitalisme telah menjadi hegemoni sekian lama, dan telah menjadi penjajah ekonomi dunia termasuk didalamnya negara-negara muslim maka pada satu titik telah mengalami kehancuran. Runtuhnya kapitalisme ini tidak serta merta membuat sistem ini hilang atau tidak dipergunakan lagi, mengingat sistem ini telah mengilhami sistem dunia yang kompleks sehingga tidak mudah bagi sistem ekonomi Islam mengubahnya dan penting menentukan tahapan-tahapan strategisnya.

Dalam konteks mekanisme pasar, secara ideal Islam dapat dirujuk dari apa yang dijelaskan oleh Ibn Taimiyah. Ibnu Taimiyah berkata: "Naik dan turunnya harga tak selalu berkait dengan kezaliman (zulm) yangdilakukan seseorang. Sesekali, alasannya 
96 | Tri Wahyuni Permasalahan dalam Penerapan Mekanisme Pasar

adalah adanya kekurangan dalam produksiatau penurunan impor dari barang-barang yang diminta. Jadi, jika membutuhkan peningkatan jumlah barang, sementara kemampuannya menurun, harga dengan sendirinya akan naik. Di sisi lain, jika kemampuan penyediaan barang menigkat danpermintaannya menurun, harga akan turun. Kelangkaan dan kelimpahan tak mesti di akibatkan oleh perbuatan seseorang. Bisa saja berkaitan dengan sebab yang tak melibatkan ketidak adilan. Atau, sesekali, bisa juga disebabkan ketidak adilan. Maha Besar Allah, yang menciptakaan kemauan pada hati manusia...”.(Ibnu Taimiyah, Majmu' fatawa). Ungkapan ini menunjukkan bahwa ada kebiasaan yang berlaku di zaman ibnu Taimiyah bahwa kenaikan harga seringkali diakibatkan oleh ketidakadilan parapelaku pasar. Pandangan ini ditolak oleh ibnu Taimiyah dengan mengungkapkan bahwa kenaikan harga tidak selamanya disebabkan zulm (ketidakadilan). Ada faktorlain yang mempengaruhinya yakni kekuatan pasar antara supply dan demand.

Dalam kitab Fatawa. Ibnu Taimiyah menjelaskan faktor-faktor yang mempengaruhi permintaan: (ekonomi Islam) dan konsekuensinya terhadap harga:

1. Ar-Raghabah (keinginan) atas barang-barang berbeda dan seringkali berubah. Hal ini turut dipengaruhi oleh berlimpah atau langkanya suatu barang. Semakin langka semakin ia diminati oleh masyarakat. Dalam konvensional faktor ini dikenal dengan istilah preference (minat).

2. Jumlah orang yang meminta. Semakin banyak orang yang meminta dalam satujenis barang dagangan, maka semakin mahal harga barang.

3. Kuat atau lemahnya permintaan. Kebutuhan tinggi dan kuat, harga akan naiklebih tinggi ketimbang jika peningkatan kebutuhan itu kecil atau lemah.

4. Kualitas pembeli (al-mu'awid). Harga juga berubah-rubah, sesuai dengan siapasaja transaksi tersebut dilakukah. Pembeli yang memiliki kredibilitas yang buruk,sering bankrut, mengulur-ulur pembayaran akan mendaoatkan harga yang lebihtinggi dari pembeli yang memiliki predikat baik.

5. Jenis uang yang digunakan. Harga juga dipengaruhi oleh bentuk alat pembayaran(uang) yang digunakan dalam jual beli. Jika yang digunakan adalah naqd raji, harga akan lebih rendah ketimbang membayar dengan uang yang jarang ada diperedaran. 
Hal diatas dapat terjadi karena tujuan dari suatu transaki harus menguntungkan penjual dan pembeli. Jika pembeli memiliki kemampuan untuk membayar dan dapat memenuhi janjinya, maka transaksi akan lebih mudah/lancar. Aplikasi yang sama berlaku bagi sesorang yang meminjam atau menyewa. Adanya biaya tambahan akan mengakibatkan perubahan harga. Menyewa tanahdalam kondisi banyaknya perampok atau hewan liar akan menambah beban bagipenyewa, sehingga harga sewa lebih rendah dibanding tanah yang tidak membutuhkan biaya tambahan. Kemudian mengenai penetapan (regulasi) harga dikenal dalam dunia fiqih dengan istilah tas'ir yang berarti, menetapkan harga tertentu pada barang-barang yang diperjual belikan dimana tidak mendzalimi pemilik barang dan pembelinya.

Dalam konsep ekonomi Islam penentuan harga dilakukan oleh kekuatan-kekuatan pasar yaitu kekuatan permintaan dan penawaran. Dalam konsep Islam, pertemuan permintaan dengan penawaran tersebut haruslah terjadi secara rela sama rela, dalam artian tidak ada pihak yang terpaksa untuk melakukan transaksi pada tingkat harga tertentu. Keadaan rela sama rela merupakan kebalikan dari keadaan aniaya yaitu keadaan dimana salah satu pihak senang diataskesedihan pihak lainnya. Dalam hal harga, para ahli fiqih merumuskannya sebagai The Price of The Equivalent (Tsamanul Mitsly). Selanjutnya bagaimana jika sistem Islam diterapkan namun terjadipenyimpangan dari kondisi normal? Menurut Islam negara memiliki hak untukmelakukan intervensi dalam kegiatan ekonomi baik itu dalam bentuk pengawasan,pengaturan maupun pelaksanaan kegiatan ekonomi yang tidak mampu dilaksanakanoleh masyarakat. Intervensi harga oleh pemerintah bisa karena faktor alamiah maupun non alamiah. Intervensi dengan cara membuat kebijakan yang dapatmempengaruhi dari sisi permintaan maupun dari sisi penawaran (marketintervention) biasanya dikarenakan distorsi pasar karena faktor alamiah.

Bila distorsi pasar terjadi karena faktor non almiah, maka kebijakan yang ditempuh salah satunya dengan dengan intervensi harga di pasar. Dengan segala kebijakannya untuk mengatur,negara sangat berwenang untuk mengatur dengan orientasi demi kemaslahatan umat. Demikian paparan bagaimana sistem ekonomi Islam mempunyai tatanan mengenai mekanisme pasar. Adalah sebuah harapan sistem ini dapat berjalan secara ideal sehingga kesenjangan ekonomi dapat diminimalisir. 
98 | Tri Wahyuni Permasalahan dalam Penerapan Mekanisme Pasar................

\section{Solusi Islam Terhadap Ketidaksempurnaan Bekerjanya Pasar}

Solusi Islam terhadap Ketidak sempurnaan Bekerjanya Pasar. Larangan Ikhtikar Rasulullah telah melarang praktek ikhtikar, yaitu secara sengaja menahanatau menimbun barang, terutama pada saaat terjadinya kelangkaan, dengan tujuanuntuk menaikan harga di kemudian hari. Akibat dari ikhtikar ini masyarakat luasakan dirugikan oleh sekelompok kecil yang lain. Agar harga dapat kembali ke posisi semula maka pemerintah dapat melakukan berbagi upaya menghilangkan penimbuanan ini. Namun tidak termasuk ikhtikar adalah penumpukan yang dilakukan pada situasi ketika pasokan melimpah, misalnya penimbunan atau penahanan pada saat panen besar, dan segera menjualnya pada saat pasar membutuhkan.

Membuka Akses Informasi Beberapa larangan terhadap praktik penipuan pada dasarnya adalah upaya untuk menyebarkan keterbukaan informasi sehingga transaksi dapat dilakukan dengan sama-sama suka dan adil. Beberapa larangan ini antara lain talaqirukhban (membeli barang dengan cara mencegah para penjual di luar kota), baynajasyi (mencakup pengertian kolusi dimana antar penjual satu dengan yang lainnya melakukan kerja samauntuk menipu konsumen), ghaban fahisy (upaya sengaja untuk mengaburkan informasi sebab penjual memanfaatkan ketidak tahuan konsumen untuk mencari keuntungan yang tinggi.

Regulasi harga pada dasarnya jika pasar sudah bekerja dengan sempurna, maka tidak ada alasan untuk mengatur tingkat harga. Penetapan harga justru akan mendistorsi harga sehingga akhirnya mengganggu mekanisme pasar itu sendiri. Jadi regulasi harga dapat dilakukan pada situasi tertentu saja. Pemerintah dapat melakuakan regulasi harga apabila pasar bersaing tidak sempurna, dan keadaan darurat. Apabila terpaksa menentapkan harga, maka konsep harga yang adil harus menjadi pedoman. Adapun beberapa keadaan darurat diantaranya adalah harga naik sedemikian tinggi di luar kewajaran, menyangkut barang-barang yang amat dibutuhkan masyarakat, terjadi ketidak adilan. 
Ekonomica Sharia Volume 5 Nomor 1 Edisi Agustus 2019 |99

\section{SIMPULAN}

Pasar adalah tempat untuk beraktifitas ekonomi dimana kegiatan ekonomi berlangsung secara alamiah sehingga aturan mainnya pun terjadi secara alamiah. Sehingga menurut ekonomi Islam mekanisme pasar dapat terjadi secara alamiah dari sisi penawaran dan permintaan sebagaimana mestinya. Selanjutnya dalam hal mekanisme pasar perspektif ekonomi Islam pada prinsipnya adalah menolak adanya suatu price intervention seandainya perubahan harga terjadi karena mekanisme pasaryang wajar. Namun, pasar di sini mengharuskan adanya moralitas, anatara lain: persaingan yang sehat (fair play), kejujuran (honesty), keterbukaan (transparancy), dan keadilan (justice). Jika nilai-nilai ini telah ditegakkan, maka tidak ada alasan untukmenolak harga pasar. Dan jika terjadi penyimpangan maka kewajiban negara untuk mengaturnya demi kemaslahatan umat. 
100 | Tri Wahyuni Permasalahan dalam Penerapan Mekanisme Pasar..............

\section{DAFTAR PUSTAKA}

Abu Yusuf ibn Ya'qub ibn Ibrahim, (1979), Kitab al-Kharaj, (Beirut: Dar al-Ma'rifah li ath-Thiba'ah wa an-Nasyr) atau lihat Abul Hasan M. Sadeq dan Aidit Ghazali (eds.),(1992), Readings in Islamic Economic Thought (Malaysia: Longman Malaysia

Abul Hasan M. Sadeq, "al-Ghazali on Economic Issues and Some Ethico-Juristic MattersHaving Implications for Economic Behaviour", dalam Abul Hasan M. Sadeq dan Aidit Ghazali(Ed), Readings in Islamic Economic Thought (Malaysia: Longman Malaysia)

Adam Smith, (1937), An Inquiry Into The Nature and Causes of the Wealth of Nations, (NewYork: The Modern Library)

Adiwarman A. Karim, (2007), Ekonomi Mikro Islami, Ed. 3, (Jakarta: Raja GrafindoPersada)

Aravik, Havis, 2016. Ekonomi Islam; Teori, Konsep dan Aplikasi Serta Pandangan Pemikir Ekonomi Islam dari Abu Ubaid Sampai Al-Maududi, Malang: Empat Dua.

Charles Issawi, “Ibn Khladun's Analysis of Economics Issues”, dalam Ibid., Disarikan dari MM. Metwally, (1995), Teori dan Model Ekonomi Islam, (Jakarta: PT.Bangkit Daya Insana) 